\title{
THE EVALUATION OF SURROGACY'S LEGAL SYSTEM IN INDONESIA AS COMPARISON TO INDIA'S LEGISLATION
}

\author{
Mega Dewi Ambarwati, Ghina Azmita Kamila \\ Master's Program in Law, Faculty of Law, Airlangga University Surabaya \\ mega10meggy@gmail.com
}

Abstract

This article has been retracted from the journal Diponegoro Law Review Vol. 4 No. 2, October 2019.

Please refer to the article THE EVALUATION OF SURROGACY'S LEGAL SYSTEM IN INDONESIA AS COMPARISON TO INDIA'S LEGISLATION on the following link: https://jurnal.unej.ac.id/index.php/eJLH/article/view/10842 